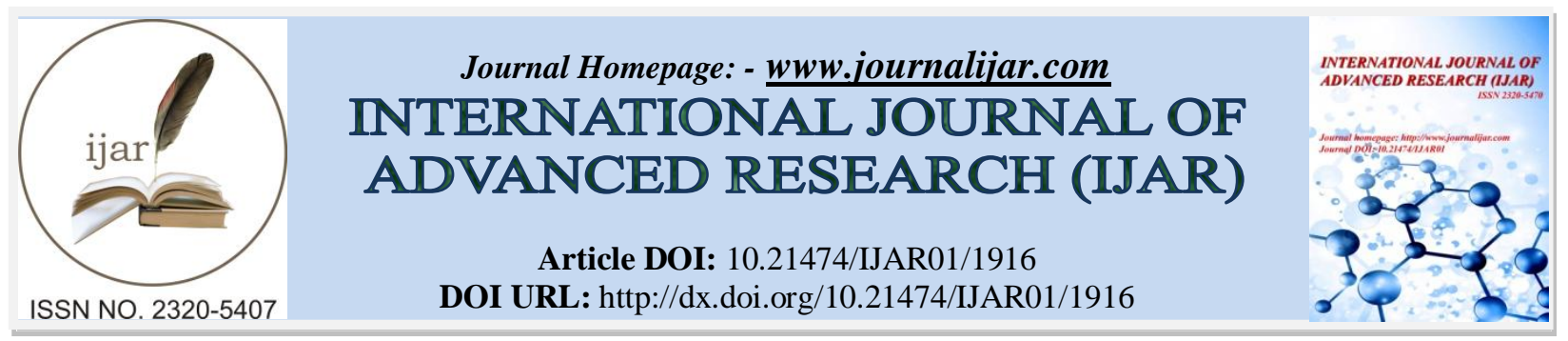

RESEARCH ARTICLE

\title{
CAN PEOPLE IMPLANTED WITH 18CT GOLD ALLOY USE DANT KANTI TOOTHPASTE?
}

\author{
Renita D'souza $^{1 *}$, Susai Rajendran ${ }^{3}$ and Amit Chattree ${ }^{2}$. \\ 1. Department of Chemistry, SHIATS, Allahabad, 211007, UP, India. \\ 2. Associate Professor and the Head of the Department of Chemistry, Sam Higginbottom Institute of Agriculture, \\ Technology and Sciences (Deemed to be University), Allahabad. 211007, UP, India. \\ 3. Department of Chemistry, Editor - in- Chief IJNCSE, Professor of Chemistry, St Antony's College of Arts \\ and Sciences for Women, Amala Annai Nagar, Thamaraipadi (Post), Dindigul -624 005, India.
}

\section{Manuscript Info}

-........................

Manuscript History

Received: 12 August 2016

Final Accepted: 26 September 2016

Published: October 2016

Key words:-

Artificial saliva, corrosion potential, corrosion current, orthodontic wires, 18ct gold, double layer capacitance.

\section{Abstract}

Corrosion resistance of $18 \mathrm{ct}$ gold has been evaluated in artificial saliva in the absence and presence of five toothpastes namely Vicco, Dant Kanti, Sparkle Fresh, Emoform and Colgate Visible White by electrochemical studies. It's observed that $18 \mathrm{ct}$ gold + AS+ toothpaste system is more corrosion resistant.

In polarization study when corrosion resistance increases, linear polarization resistance (LPR) increases and corrosion current ( $\left.\mathrm{I}_{\text {corr }}\right)$ decreases. In AC impedance spectra, when corrosion resistance increases, charge transfer resistance $\left(\mathrm{R}_{\mathrm{ct}}\right)$ increases ; double layer capacitance $\left(\mathrm{C}_{\mathrm{dl}}\right)$ decreases; the impedance increases.

Among the five toothpastes studied the Dant Kanti offers better corrosion resistance to $18 \mathrm{ct}$ gold. For this system, LPR $=2528937 \mathrm{ohm}$ $\mathrm{cm}^{2} ; \mathrm{I}_{\text {corr }}=1.338 \times 10^{-8} \mathrm{~A} / \mathrm{cm}^{2} ; \mathrm{R}_{\mathrm{ct}}=10870 \mathrm{ohm} \mathrm{\textrm {cm } ^ { 2 }} ; \mathrm{C}_{\mathrm{dl}}=4.6918 \times 10^{-10}$ $\mathrm{F} / \mathrm{cm}^{2}$ and impedance $=4.415 \mathrm{logz} / \mathrm{ohm}$. The high corrosion resistance offered by the Dant Kanti toothpaste is due to formation of a compact, stable, protective film on the surface of $18 \mathrm{ct}$ gold.

The surface morphology of the protective film has been analysed with the help of UV-Visible absorption spectra, fluorescence spectra, FTIR, SEM and EDX. They confirm the presence of protective film formed on the metal surface. The active principles of the ingredients of the toothpaste have co-ordinated with the gold ions on the metal surface through their polar atoms. EDX spectra reveal that there is increase in the intensity of the peaks in the presence of toothpaste solution.

Copy Right, IJAR, 2016,. All rights reserved.

\section{Introduction:-}

Depending on the environment of mouth the traces of corrosion on the surfaces of metals used in orthodontic wires can be formed after a period of time (House et al., 2008). The corrosion process occurs as a result either of the loss of metal ions directly into the solution or of the progressive dissolution of the surface films. Corrosion resistance is one of the important features of dental materials, because after introducing into the human body, the metallic biomaterials are subject to corrosive medium. 
During treatment, fixed orthodontic appliances are placed in the oral cavity for around 2-3 years and are exposed to physical and chemical factors that may cause corrosion and passivation (Sfondrini et al., 2009; Fernandez-Minano et al., 2011). As a result of saliva flow, chewing, brushing, and friction between brackets and wires, as well as the effect of acidic drinks, mouthwash, toothpaste, and biofilm formation, the surfaces of the elements of the appliance are modified (Harzer et al., 2001; Amini et al., 2012).

Under several situations the oral environment is highly aggressive and leads to corrosion. Corrosion is a chemical or electrochemical process by which metal is attacked by ordinary substances, causing a partial or complete dissolution, deterioration, and weakness. It results in catastrophic disintegration of metals. While some metallic elements are completely safe others can form toxic compounds. Hence degradation of metals used for orthodontic treatment should be limited in order to guarantee its life (Duff and Farina, 2009)

The most favourable archwire material/bracket is the one which is capable of resisting the most extreme conditions that could possibly be encountered in the mouth. Orthodontic alloys must have excellent corrosion resistance to the oral environment, which is highly important for biocompatibility as well as for orthodontic appliance durability. It is known that the quality and performances of dental materials are beside the proper composition of dental alloy, the good mechanical properties, the corrosion resistance and the biocompatibility (POP et al., 2013). Metal alloys are widely used materials in prosthetic dentistry due to their high durability and good mechanical properties. In dentistry, both precious alloys and non-precious alloys are used (Klimek et al., 2005).

Gold was the first metal used for the fabrication of oral restorations. The gold bridges were attached inside of the mouth using wires. Gold has traditionally found use because of its good resistance to oxidative corrosion. Gold itself is considered chemically inert and biologically compatible with the body. If longevity, functionality, aesthetics, and biocompatibility, together with ease of manufacture are considered as the most important requirements, the optimum material for dental restorations is gold alloy. It is interesting to note that if practicing dentists are asked what type of material for a restoration they prefer for themselves, with few exceptions the answer is always gold.

During the dental treatment, a patient makes use of various toothpastes and toothpowder to clean their teeth. Hence it is essential to evaluate the corrosion resistance of orthodontic wire in the oral environment using the available toothpastes. The following work was undertaken to study the corrosion behaviour of $18 \mathrm{ct}$ gold in artificial saliva, in the absence and presence of a toothpaste Dant Kanti.

\section{Experimental:-}

Materials:-

The metal specimen chosen for the present study was $18 \mathrm{ct}$ gold and the toothpaste was Dant Kanti. The medium used was artificial saliva (AS). The composition of AS is given in Table 1 (Rajendran et al., 2009; Meyer et al., 1977; Christoper et al., 2002).

Table 1:- Composition of artificial saliva (Fusayama Meyer)

\begin{tabular}{|l|l|}
\hline Content & ${\text { Quantity } \mathbf{~ g L}^{-1}}^{-1}$ \\
\hline $\mathrm{KCl}$ & 0.4 \\
\hline $\mathrm{NaCl}$ & 0.4 \\
\hline $\mathrm{CaCl} 2.2 \mathrm{H}_{2} \mathrm{O}$ & 0.906 \\
\hline $\mathrm{NaH}_{2} \mathrm{PO}_{4} 2 \mathrm{H}_{2} \mathrm{O}$ & 0.690 \\
\hline $\mathrm{Na}_{2} \mathrm{~S} \cdot 9 \mathrm{H}_{2} \mathrm{O}$ & 0.005 \\
\hline Urea & 1 \\
\hline
\end{tabular}

The composition of $18 \mathrm{ct}$ gold:-

Gold-75\%, Copper-5-15\% and Silver-10-20\% (Krishnaveni et al., 2013).

\section{Composition of Dant Kanti:-}

(weight(mg)/10 g): Anacyclus pyrethrum-20, Azadirachta indica-10, Acacia Arabica-20, Xanthoxylum alatum-20, Mentha Spicata-10, Syzygium aramaticum-10, Piper sylvaticum-10, Barleria prionitis-10, Mimusops elengi-10, Embelia ribes-10, Curcuma longa-10, Salvadora persica-10, Quercus infectoria-10. 


\section{Methods:- \\ Potentiodynamic polarization:-}

Polarization studies were carried out in a CHI-Electrochemical workstation with impedance, Model 660A. A three electrode cell assembly was used. The working electrode was one of the metals. A saturated calomel electrode (SCE) was the reference electrode and platinum was the counter electrode. From the polarization study, corrosion parameters such as corrosion potential $\left(\mathrm{E}_{\text {corr }}\right)$, corrosion current $\left(\mathrm{I}_{\text {corr }}\right)$, linear polarization resistance(LPR) and Tefel slopes (anodic $=b_{a}$ and cathodic $=b_{c}$ ) were calculated.

\section{AC impedance spectra:-}

The instrument used for polarization study was used to record AC impedance spectra also. The cell set up was also the same. The real part (Z') and imaginary part (Z") of the cell impedance were measured in ohms at various frequencies. Values of the charge transfer resistance $\left(R_{t}\right)$ and the double layer capacitance $\left(C_{d 1}\right)$ were calculated from Nyquist plots. Impedance $\log (\mathrm{Z} / \mathrm{ohm})$ was calculated from Bode plots. During AC impedance spectra were recorded the scan rate $(\mathrm{V} / \mathrm{s})$ was 0.005 ; Hold time at $\mathrm{Ef}(\mathrm{s})$ was zero and quite time (s) was 2 . The value of charge transfer resistance $\left(\mathrm{R}_{\mathrm{t}}\right)$ and double layer capacitance $\left(\mathrm{C}_{\mathrm{dl}}\right)$ were calculated from Nyquist plot.

$$
\mathbf{R}_{\mathrm{t}}=\left(\mathbf{R}_{\mathrm{s}}+\mathbf{R}_{\mathrm{t}}\right)-\mathbf{R}_{\mathrm{s}}
$$

Where $\mathrm{R}_{\mathrm{s}}=$ Solution resistance, $\mathrm{R}_{\mathrm{t}}=$ Charge transfer resistance

$$
C_{d l}=\quad 2 \times 3.14 \times R_{t} \times f_{\max }
$$

Where $\mathrm{f}_{\max }=$ frequency at maximum imaginary impedance.

\section{Surface characterization studies:-}

The thin wire metal specimen was immersed in an inhibitor system, for a period of one day. The specimen was taken out, dried and the nature of the film formed on the surface of the metal specimen was analyzed by surface analysis techniques.

\section{Scanning electron microscopic study (SEM):-}

The surface morphology was examined for the thin wire metal specimen in absence and in the presence of the inhibitor system by using Tescon, Vega3, and USA computer controlled scanning electron microscope. The specimen immersed in the system for a period of one day was removed, rinsed with double distilled water, dried and observed in a scanning electron microscope to examine the surface morphology.

\section{Energy dispersive analysis of X-rays (EDAX):-}

SEM imaging gives the morphological data for a sample; however by using $\mathrm{x}$-ray spectroscopy in conjunction with SEM, the elemental composition can be determined. The elements present in a material are determined by an EDAX spectrum. An energy dispersive X-ray analyzer (EDAX) [Brucker, Nano, GMBH, Germany] unit attached to the SEM machine was used to carry out the elemental analysis of the metal surface.

\section{Surface analysis by FTIR spectra:-}

The FTIR spectra were recorded for the inhibitor and for the film formed on the thin wire metal specimen surface. A thin layer of inhibitor was applied on the metal surface, dried and was carefully scratched off. It was then mixed with $\mathrm{K} \mathrm{Br}$ and made into pellets and the FTIR spectrum was recorded. The FTIR spectrum of film formed on the surface of thin wire metal specimen were recorded after immersion period of one day in artificial solution containing toothpaste Dant Kanti. The specimens were taken out of the test solutions and dried. The film formed on the surface was scratched carefully and it was thoroughly mixed with $\mathrm{K} \mathrm{Br}$, and made into pellets. FTIR spectrum of the powder (K Br pellet) was recorded using Perkin -Elmer 1600 FTIR spectrophotometer with a resolving power of $4 \mathrm{~cm}^{-1}$.

\section{UV- Visible absorption spectra of solutions:-}

The possibility of the formation of metal - inhibitor complex in solution was examined by recording their UVVisible absorption spectra for the blank, the inhibitor and the best system solution using Analytic Jena Specord S100, UV -Visible spectrometer. 
Fluorescence spectroscopy:-

Fluorescence spectra of solutions, blank, the inhibitor and the best system were recorded by Using Jasco- 6300 spectroflurometer.

\section{Results and Discussion:-}

Analysis of potentiodynamic polarization curves:-

The polarization curves of $18 \mathrm{ct}$ gold immersed in various test solutions are shown in Fig 1. The corrosion parameter namely, corrosion potential $\left(\mathrm{E}_{\text {corr }}\right)$, Tafel slopes $\left(\mathrm{b}_{\mathrm{c}}=\right.$ cathodic; $\mathrm{b}_{\mathrm{a}}=$ anodic), linear polarization resistance $(\mathrm{LPR})$ and corrosion current $\left(\mathrm{I}_{\text {corr }}\right)$ derived from polarization curves are given in Table 2.

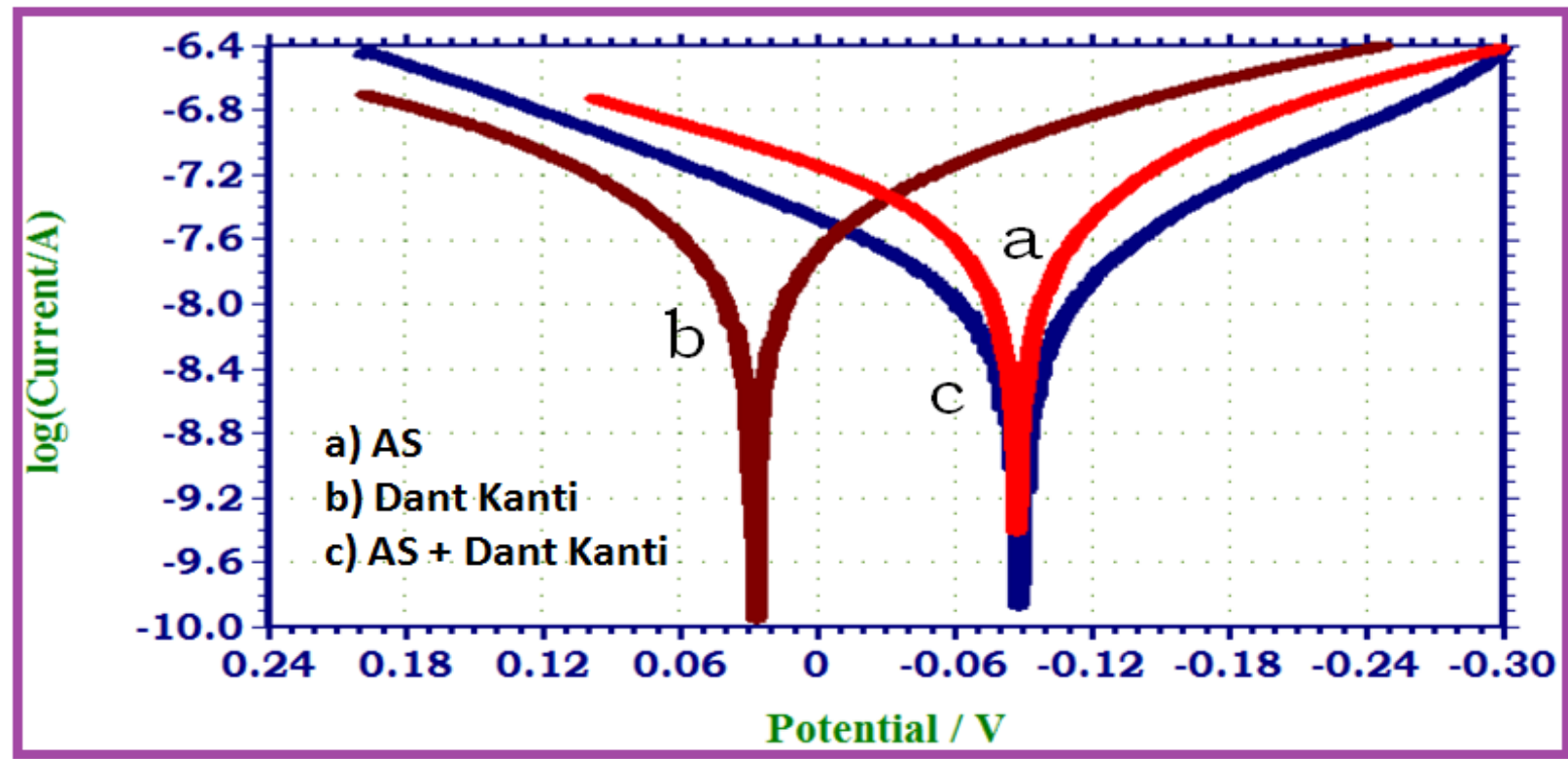

Fig 1:- Polarization curves of 18 ct gold immersed in artificial saliva (AS) in the absence and presence of toothpaste

(a) Artificial Saliva (AS)

Dant Kanti

b) Dant Kanti toothpaste(1\%)

(c) AS + Dant Kanti toothpaste(1\%)

Table 2:- Corrosion parameters of $18 \mathrm{ct}$ gold immersed in various test solutions obtained from polarization study.

\begin{tabular}{|l|l|l|l|l|l|}
\hline System & $\begin{array}{l}\mathbf{E}_{\text {corr }} \\
\text { mVvs SCE }\end{array}$ & $\begin{array}{l}\mathbf{b}_{\mathbf{c}} \\
\mathbf{m V / d e c a d e}\end{array}$ & $\begin{array}{l}\mathbf{b}_{\mathbf{a}} \\
\mathbf{m V / d e c a d e}\end{array}$ & $\begin{array}{l}\text { LPR } \\
\text { Ohm } \mathbf{~ c m}^{\mathbf{2}}\end{array}$ & $\begin{array}{l}\mathbf{I}_{\text {corr }} \\
\mathbf{A} / \mathbf{c m}^{\mathbf{2}}\end{array}$ \\
\hline AS & -087 & 155 & 224 & 1080517 & $3.700 \times 10^{-8}$ \\
\hline Dant Kanti & 027 & 168 & 157 & 1304875 & $2.715 \times 10^{-8}$ \\
\hline AS + Dant Kanti & -088 & 136 & 181 & 2528937 & $1.338 \times 10^{-8}$ \\
\hline
\end{tabular}

This observes that when $18 \mathrm{ct}$ gold immersed in AS, the corrosion potential is $-087 \mathrm{mV}$ vs SCE. The linear

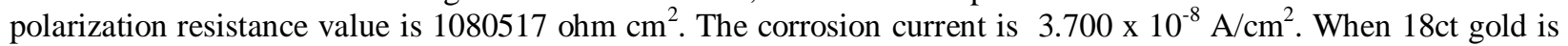
immersed in aqueous solution of Dant Kanti(1\%), the corrosion potential is shifted to noble side (027 mV vs SCE). The linear polarization resistance (LPR) value increases from $1080517 \mathrm{ohm} \mathrm{cm}{ }^{2}$ to $1304875 \mathrm{ohm} \mathrm{cm}^{2}$. The corrosion current decreases from $3.700 \times 10^{-8} \mathrm{~A} / \mathrm{cm}^{2}$ to $2.715 \times 10^{-8} \mathrm{~A} / \mathrm{cm}^{2}$. These observations indicate that the anodic reaction is controlled predominantly. A protective film is formed on the metal surface. Hence linear polarization resistance (LPR) value increases and corrosion current $\left(\mathrm{I}_{\text {corr }}\right)$ decreases. The protective film may probably consist of complexes formed between gold ion and the active principles of the ingredients of tooth pastes.

When 18ct gold is immersed in aqueous solutions consisting of $\mathrm{AS}$ and the $1 \%$ pastes solutions, the corrosion potential is shifted to the cathodic side $(-088 \mathrm{mV}$ vs SCE). The shift is within $50 \mathrm{mV}$ vs SCE. Hence it is inferred that, both anodic and cathodic reactions are controlled to an equal extent i.e. there is mixed type corrosion inhibition. 
Further, the linear polarization resistance (LPR) value increases from $1080517 \mathrm{ohm} \mathrm{cm}^{2}$ to $2528937 \mathrm{ohm} \mathrm{cm}^{2}$. Corrosion current decreases from $3.700 \times 10^{-8} \mathrm{~A} / \mathrm{cm}^{2}$ to $1.338 \times 10^{-8} \mathrm{~A} / \mathrm{cm}^{2}$. These observations indicate that the corrosion resistance of $18 \mathrm{ct}$ gold increases when it is immersed in AS containing aqueous solutions of the tooth paste Dant Kanti.

\section{Analysis of AC impedance spectra:-}

The AC impedance spectra of $18 \mathrm{ct}$ gold immersed in various test solutions are shown in Fig 2, 3, 4 and 5. The Nyquist plots are shown in Fig 2. The Bode plots are shown in Fig 3, 4 and 5. The corrosion parameters derived from these plots are shown in Table 3.

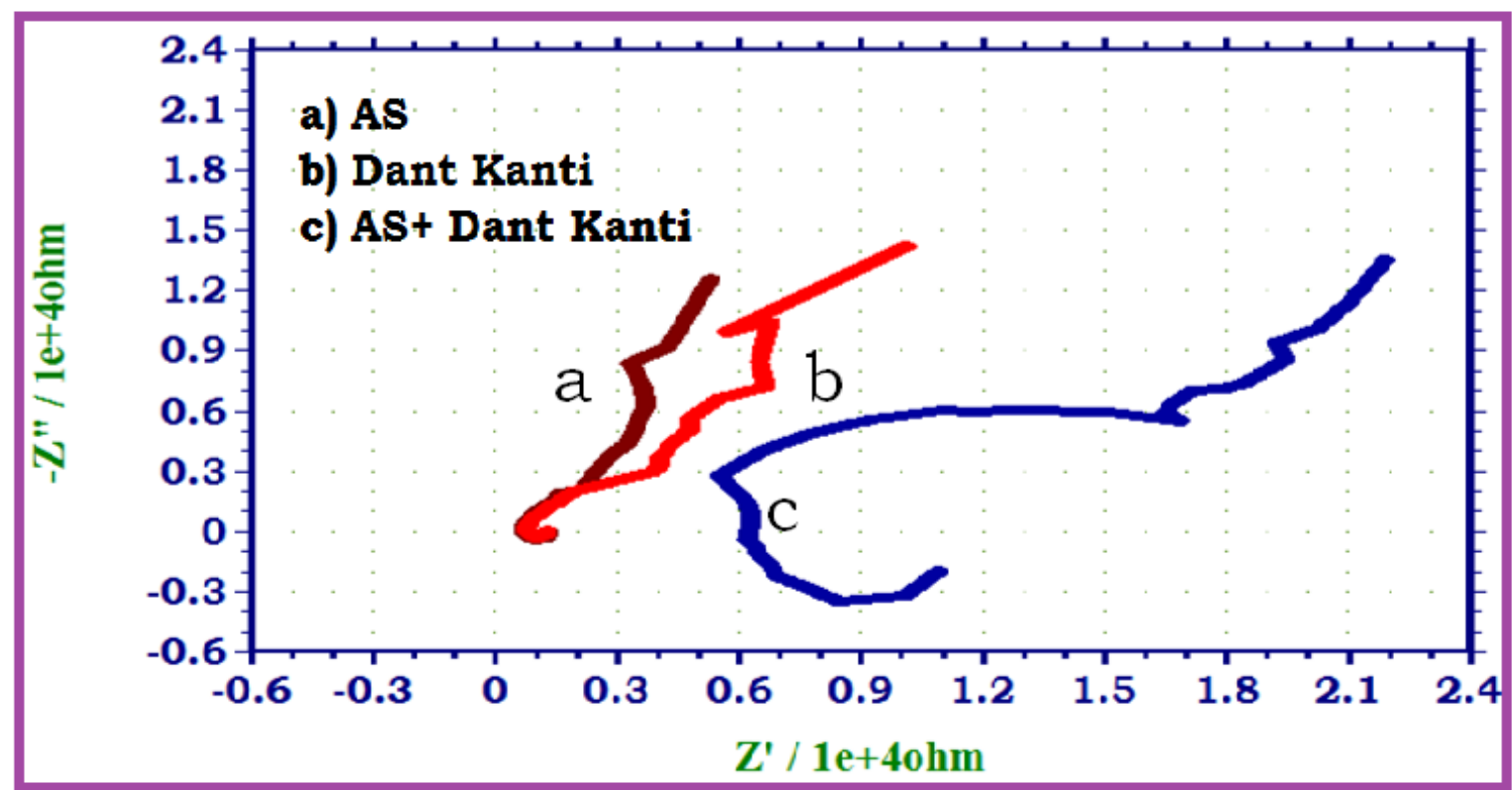

Fig 2:- AC impedance spectra of 18 ct gold immersed in artificial saliva (AS) in the absence and presence of (a) Artificial Saliva (AS) tooth paste Dant Kanti (Nyquist Plots)

(b) Dant Kanti toothpaste (1\%)

(c) AS + Dant Kanti toothpaste(1\%)

Table 3:- Corrosion parameters of $18 \mathrm{ct}$ gold immersed in various test solutions obtained from AC impedance spectra.

\begin{tabular}{|l|c|c|c|}
\hline \multirow{2}{*}{ System } & \multicolumn{2}{|c|}{ Nyquist plot } & Bode plot \\
\cline { 2 - 4 } & $\begin{array}{c}\boldsymbol{R}_{\mathbf{t}} \\
\mathbf{O h m ~ c m}^{\mathbf{2}}\end{array}$ & $\begin{array}{c}\boldsymbol{C}_{\mathbf{d l}} \\
\mathbf{F} / \mathbf{c m}^{\mathbf{2}}\end{array}$ & $\begin{array}{c}\text { Impedance value } \\
\text { Log z/ohm }\end{array}$ \\
\hline AS & 4056 & $12.573 \times 10^{-10}$ & 4.146 \\
\hline Dant Kanti & 8929 & $5.7117 \times 10^{-10}$ & 4.250 \\
\hline AS + Dant Kanti & 10870 & $4.6918 \times 10^{-10}$ & 4.415 \\
\hline
\end{tabular}




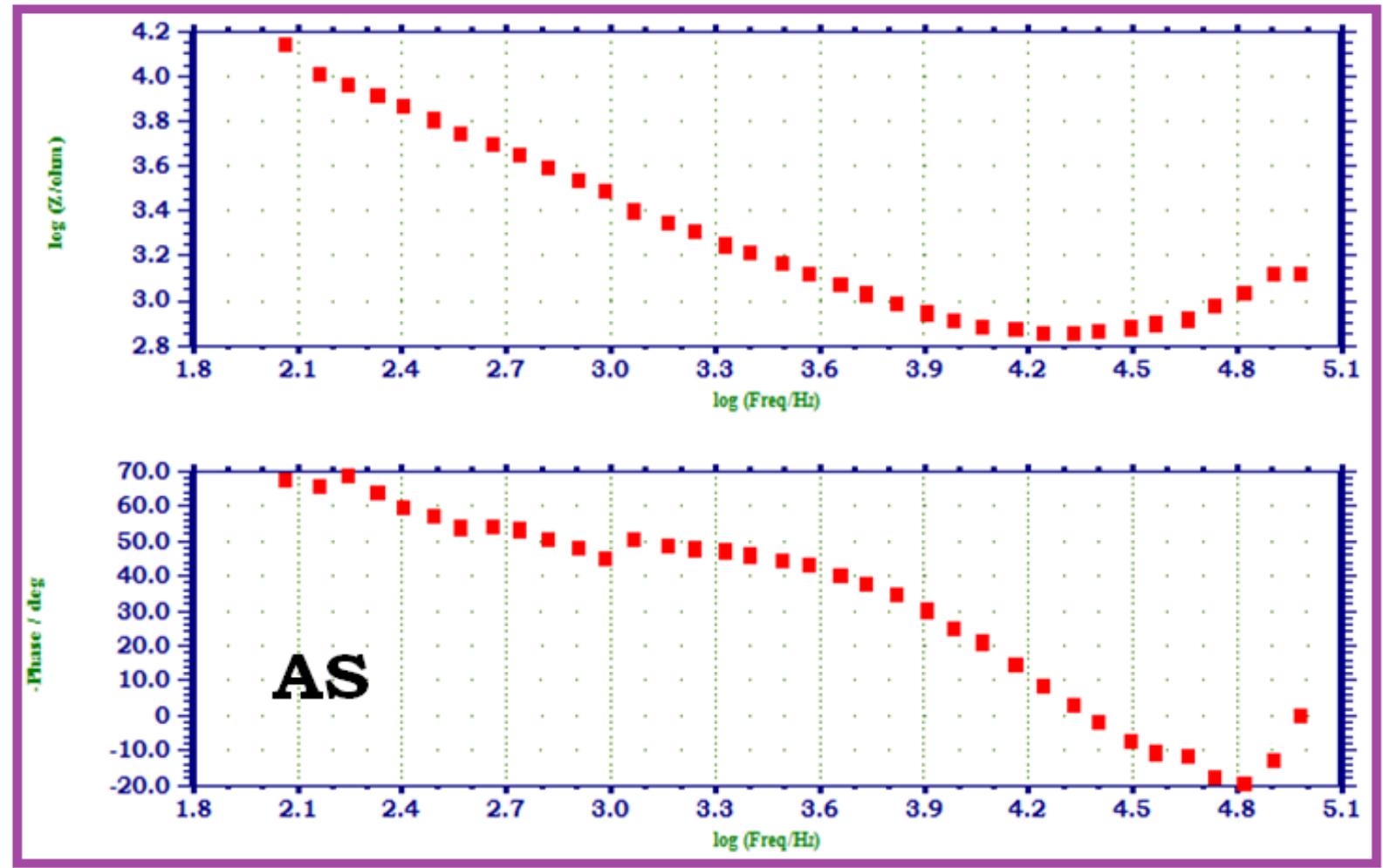

Fig 3:- AC impedance spectra of 18 ct gold immersed in artificial saliva (AS) (Bode Plots)

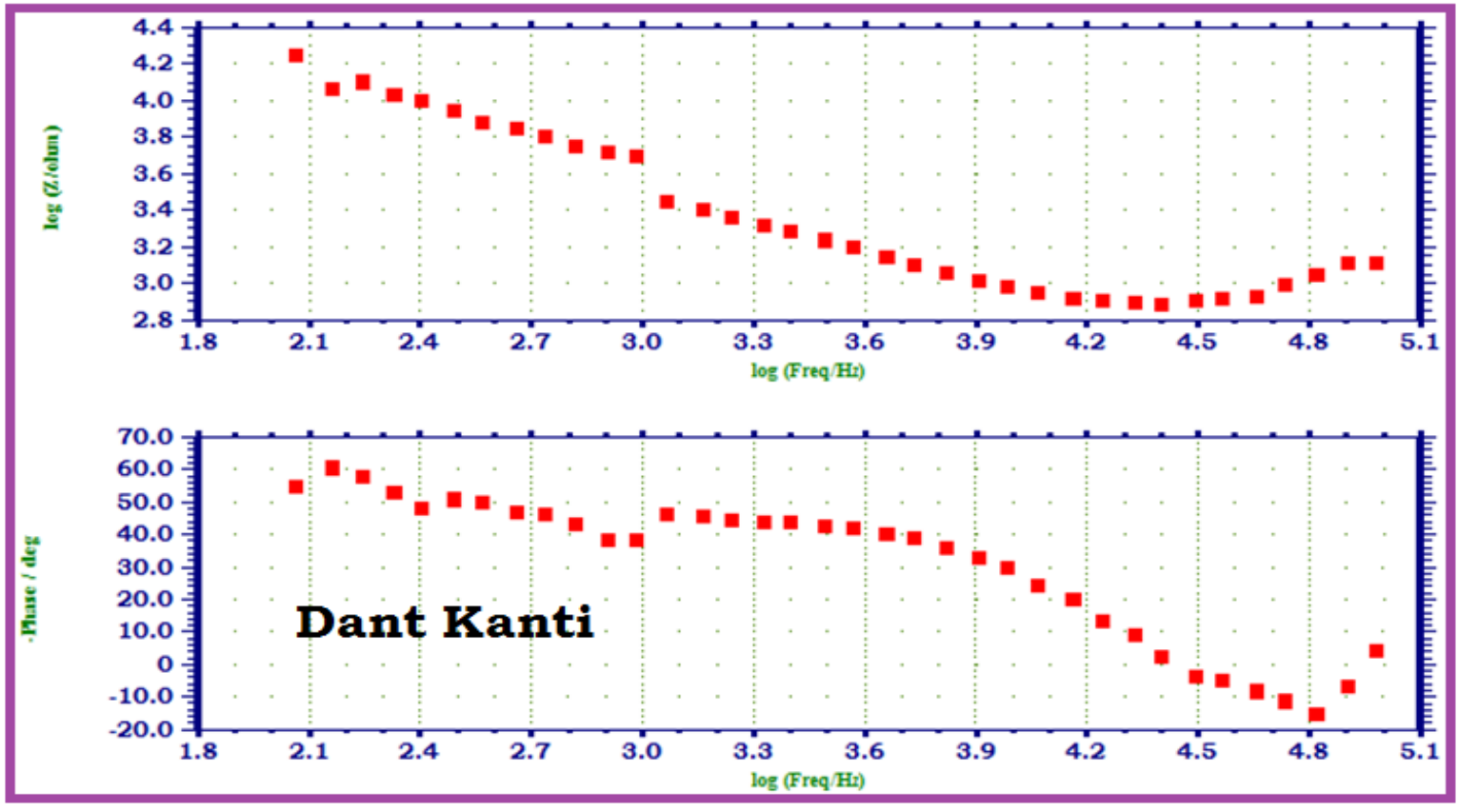

Fig 4:- AC impedance spectra of $18 \mathrm{ct}$ gold immersed in Dant Kanti toothpaste(1\%) (Bode Plots). 


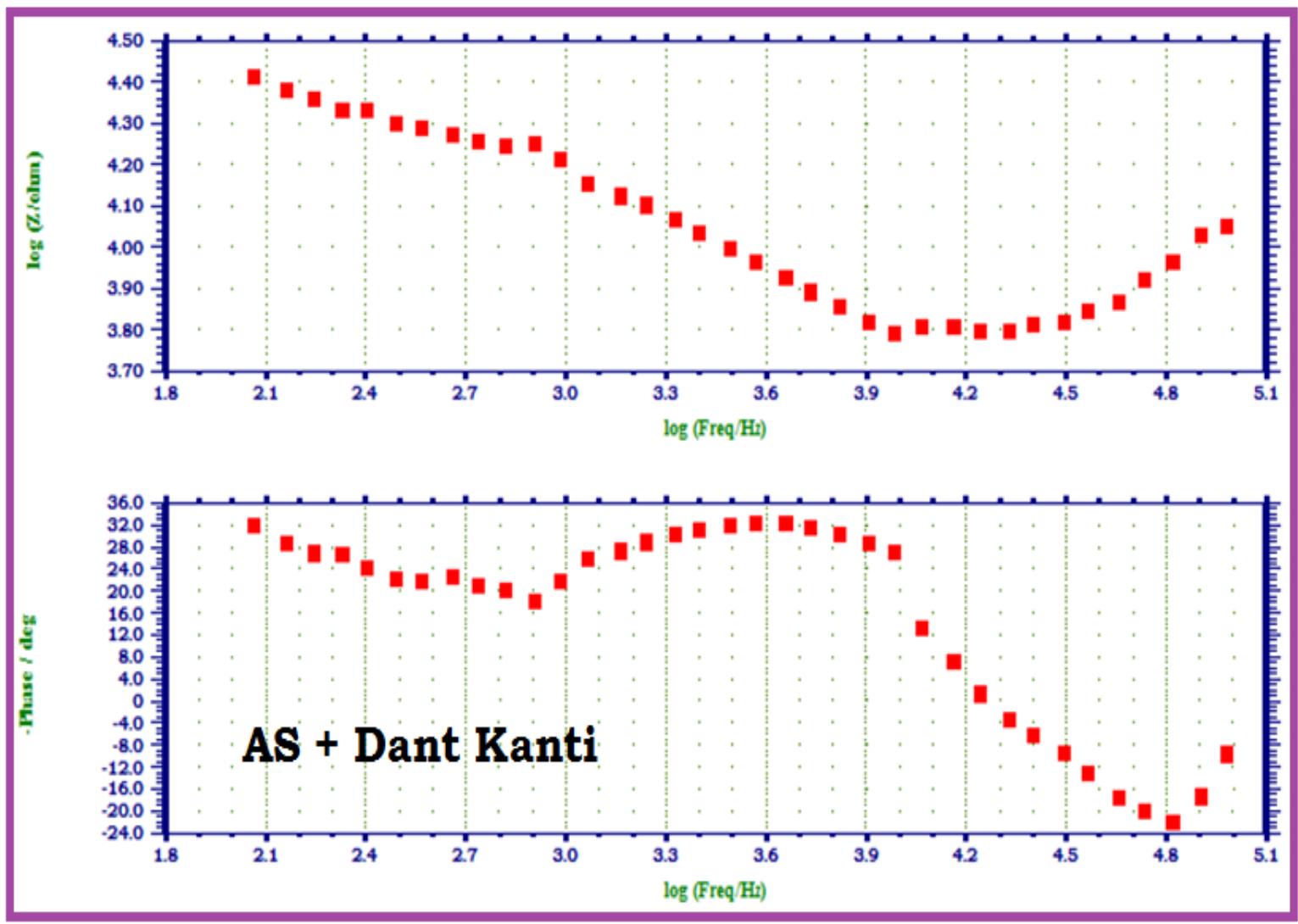

Fig 5 :- AC impedance spectra of $18 \mathrm{ct}$ gold immersed in artificial saliva(AS) in the presence of Dant Kanti toothpaste $(1 \%)$ (Bode Plots)

When 18 ct gold is immersed in AS, the charge transfer resistance $\left(\mathrm{R}_{\mathrm{t}}\right)$ value is $4056 \mathrm{ohm} \mathrm{cm}{ }^{2}$, the double layer capacitance $\left(\mathrm{C}_{\mathrm{dl}}\right)$ value is $12.573 \times 10^{-10} \mathrm{~F} / \mathrm{cm}^{2}$ and the impedance $(\log \mathrm{z} / \mathrm{ohm})$ value is 4.146 . When $18 \mathrm{ct}$ gold is immersed in aqueous solutions of $(1 \%)$ toothpaste Dant Kanti, the charge transfer resistance $\left(\mathrm{R}_{\mathrm{t}}\right)$ value increases from $4056 \mathrm{ohm} \mathrm{cm}{ }^{2}$ to $8929 \mathrm{ohm} \mathrm{cm}$, the double layer capacitance value $\left(\mathrm{C}_{\mathrm{dl}}\right)$ value decreases from $12.573 \times 10^{-10}$ $\mathrm{F} / \mathrm{cm}^{2}$ to $5.7117 \times 10^{-10} \mathrm{~F} / \mathrm{cm}^{2}$ and the impedance value (log $\mathrm{z} / \mathrm{ohm}$ ) increases from 4.146 to 4.250 . These observations indicate that, a protective film is formed on the metal surface when $18 \mathrm{ct}$ gold is immersed in aqueous solutions of tooth paste Dant Kanti. The protective film prevents the transfer of electrons from the metal surface to the bulk of the solutions. Hence corrosion resistance increases and the rate of corrosion decreases. The protective film probably consists of gold ion and the active principle of the ingredients of the tooth paste.

When 18ct gold is immersed in AS containing an aqueous solution of Dant Kanti, the charge transfer resistance $\left(\mathrm{R}_{\mathrm{t}}\right)$ value increases from $4056 \mathrm{ohm} \mathrm{cm}$ to $10870 \mathrm{ohm} \mathrm{cm}$, the double layer capacitance $\left(\mathrm{C}_{\mathrm{dl}}\right)$ value decreases from $12.573 \times 10^{-10} \mathrm{~F} / \mathrm{cm}^{2}$ to $4.6918 \times 10^{-10} \mathrm{~F} / \mathrm{cm}^{2}$, the impedance (logz/ohm) value increases from 4.146 to 4.415 . It inferred that, in presence of AS containing Dant Kanti, the corrosion resistance of 18ct gold increases.

\section{SEM analysis of metal surface:-}

The SEM images for 18ct gold in the absence and in the presence of the inhibitor system is shown in Fig 6 ( $a$ and $b$ ). Surface is found to be very smooth only for pure polished metal. But for the inhibitor system, surface has become rough due to the presence of film deposited on the metal surface. This protective film is due to the deposition of active principles of the ingredients present in the toothpaste. This protective film prevents the corrosion of $18 \mathrm{ct}$ gold in presence of artificial saliva. 

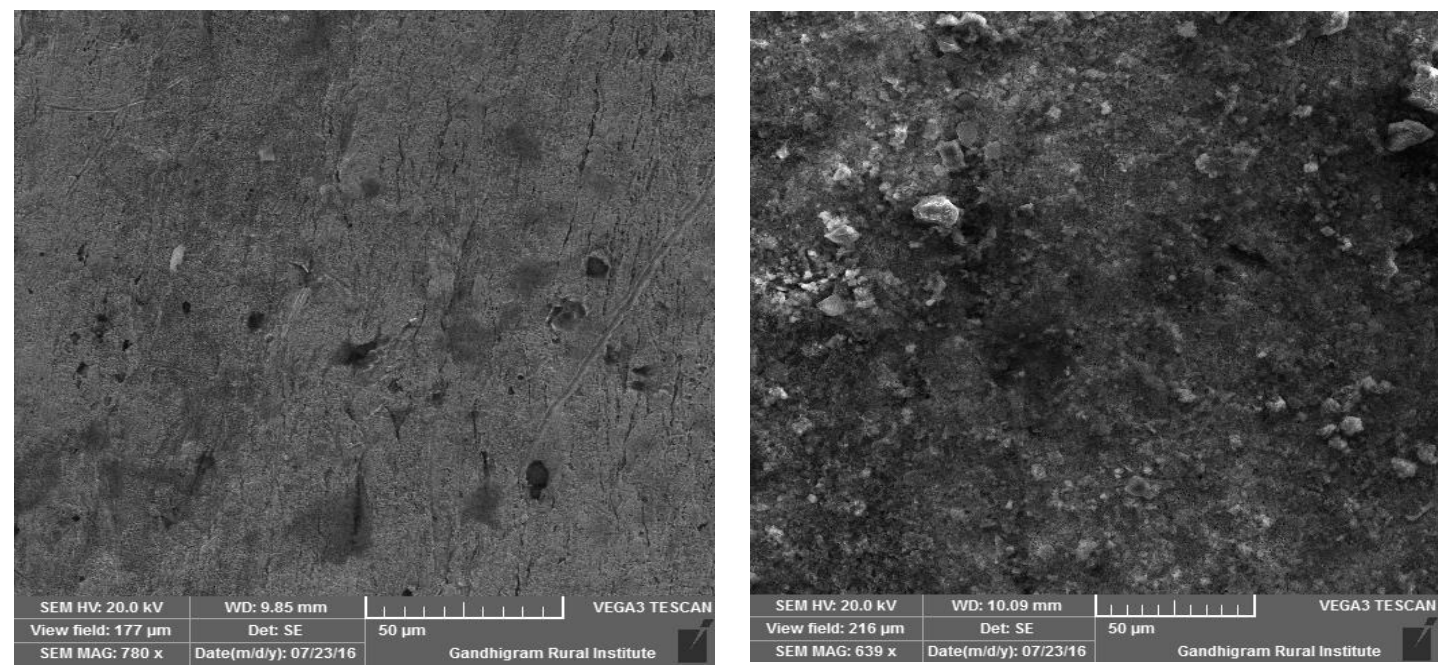

(a) Polished 18ct gold

Fig 6:- SEM images of

(b)Polished 18ct gold immersed in AS containing Dant Kanti toothpaste.

\section{Energy dispersive analysis of $\mathrm{X}$-rays (EDAX):-}

The EDAX spectra are shown in Fig 7 ( $a$ and $b$ ). It is seen from the EDAX spectra that $\mathrm{Au}$ and $\mathrm{Cu}$ are present in both absence and presence of the inhibitor ( Table 4 and 5). But the weight percentage of gold and copper has changed after immersion in the artificial saliva containing Dant Kanti toothpaste.

In the case of bare 18ct gold, because of the presence of the copper, the metal would have undergone atmospheric corrosion due to leaching out of copper and copper oxide would have formed on the metal surface. This layer would have decreased the intensity of gold (Fig 7a).

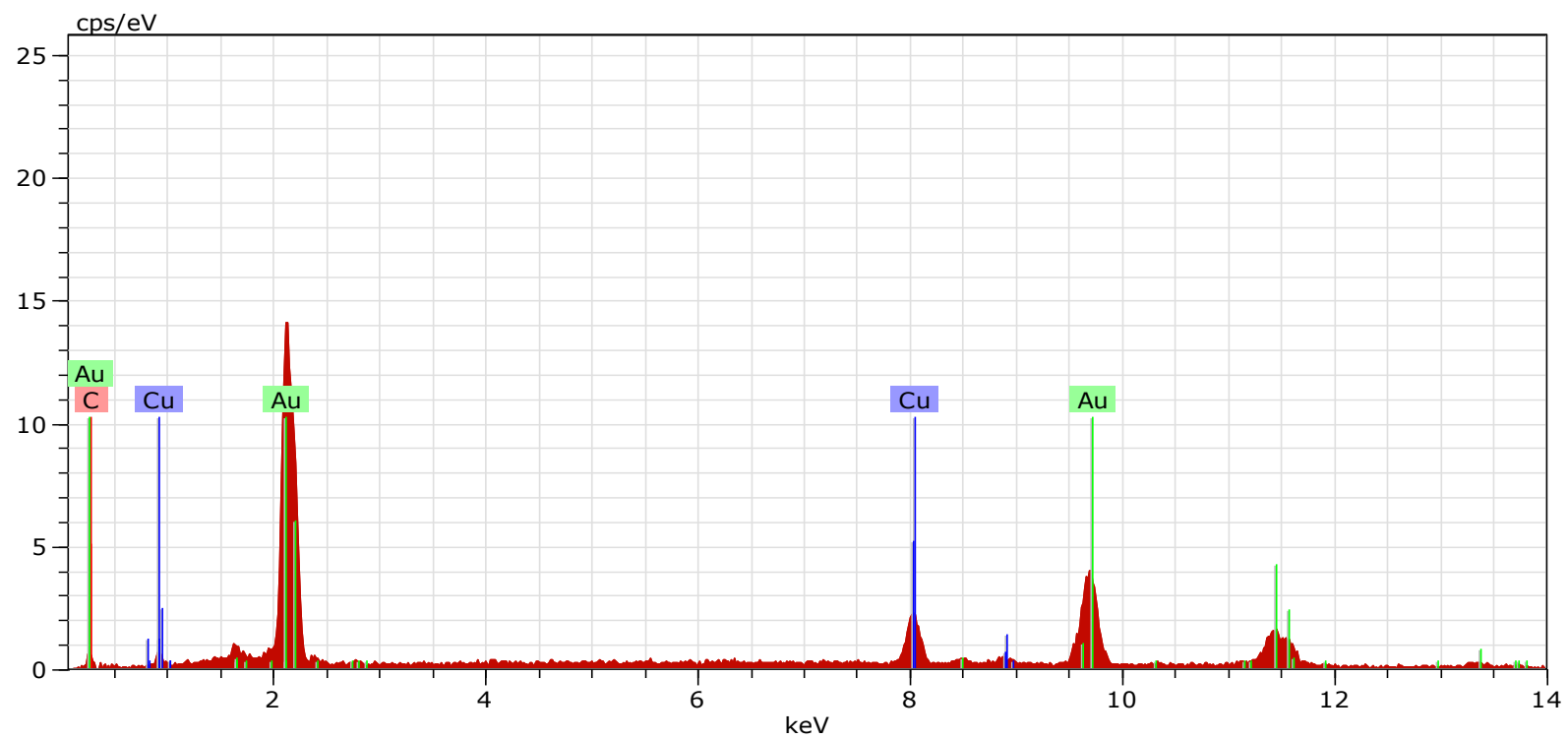




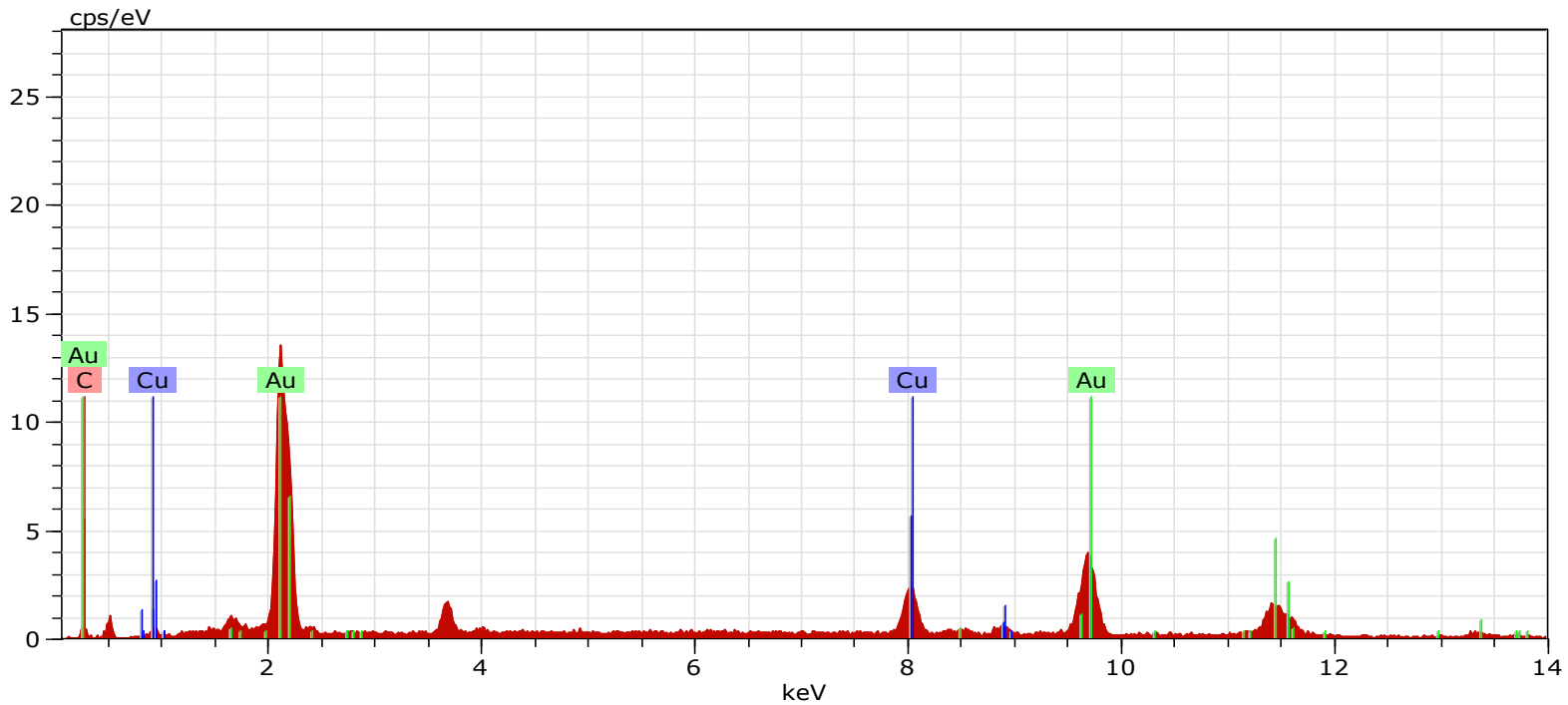

Fig 7:- EDAX spectra of

(a) Polished 18ct gold

(b)Polished 18ct gold immersed in AS containing Dant Kanti toothpaste

Table 4:- Spectrum of 18ct gold.

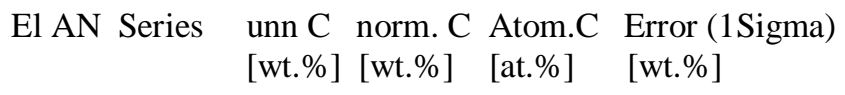

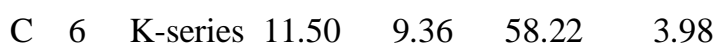

Au 79 L-series $100.04 \quad 81.38 \quad 30.89 \quad 2.73$

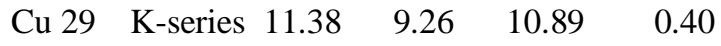

Total: $122.92 \quad 100.00 \quad 100.00$

Table 5:- Spectrum of 18 ct gold +AS+ Dant Kanti toothpaste.

\begin{tabular}{|c|c|c|c|c|c|}
\hline El AN & Series & $\begin{array}{l}\text { unn C } \\
\text { [wt.\%] }\end{array}$ & $\begin{array}{l}\text { norm. C } \\
\text { [wt.\%] }\end{array}$ & $\begin{array}{l}\text { Atom.C } \\
\text { [at.\%] }\end{array}$ & $\begin{array}{l}\text { Error (1Sigma) } \\
\text { [wt.\%] }\end{array}$ \\
\hline $\mathrm{C}$ & K-series & 9.20 & 8.20 & 54.32 & 3.38 \\
\hline Au 79 & L-series & 91.57 & 81.64 & 32.96 & 2.51 \\
\hline $\mathrm{Cu} 29$ & K-series & 11.40 & 10.16 & 12.71 & 0.39 \\
\hline
\end{tabular}

When the electrode is immersed in the environment consisting of saliva and the toothpaste, the active principles of the ingredients of the toothpaste would have formed a protective film on the metal surface, thus preventing the corrosion of $18 \mathrm{ct}$ gold. This results in the increase in the intensity of gold. The increase in corrosion resistance is supported by electrochemical studies.

\section{Analysis of FTIR spectra:-}

The FTIR (KBr) spectrum of pure toothpaste Dant Kanti is shown in Fig 8. Analysis of the structures of these compounds reveals that the active principles of the ingredients of toothpaste Dant Kanti contain functional groups like $\mathrm{OH}, \mathrm{C}=\mathrm{O}, \mathrm{S}, \mathrm{N}$ and an aromatic ring. The peak appears at $3389.38 \mathrm{~cm}^{-1}$ is due to $\mathrm{O}-\mathrm{H}$ stretching frequency. 
$2925.56 \mathrm{~cm}^{-1}$ and $2855.35 \mathrm{~cm}^{-1}$ peaks are due to $\mathrm{C}-\mathrm{H}$ stretching frequency. S-H stretching frequency was observed at $2516 \mathrm{~cm}^{-1} .1798 .35 \mathrm{~cm}^{-1}$ and $1629.58 \mathrm{~cm}^{-1}$ are due to $\mathrm{C}=\mathrm{O}$ stretching and $1085.22 \mathrm{~cm}^{-1}$ and $1048.33 \mathrm{~cm}^{-1}$ peaks are due to $\mathrm{P}-\mathrm{O}$ stretching. $1223.87 \mathrm{~cm}^{-1}$ peak is of $\mathrm{P}=\mathrm{O}$ stretching and $1085.22 \mathrm{~cm}^{-1}$ peak is of $\mathrm{C}-\mathrm{N}$ stretching. Peak at $1424.98 \mathrm{~cm}^{-1}$ indicate the presence of aromatic ring in the compounds present in the toothpaste.

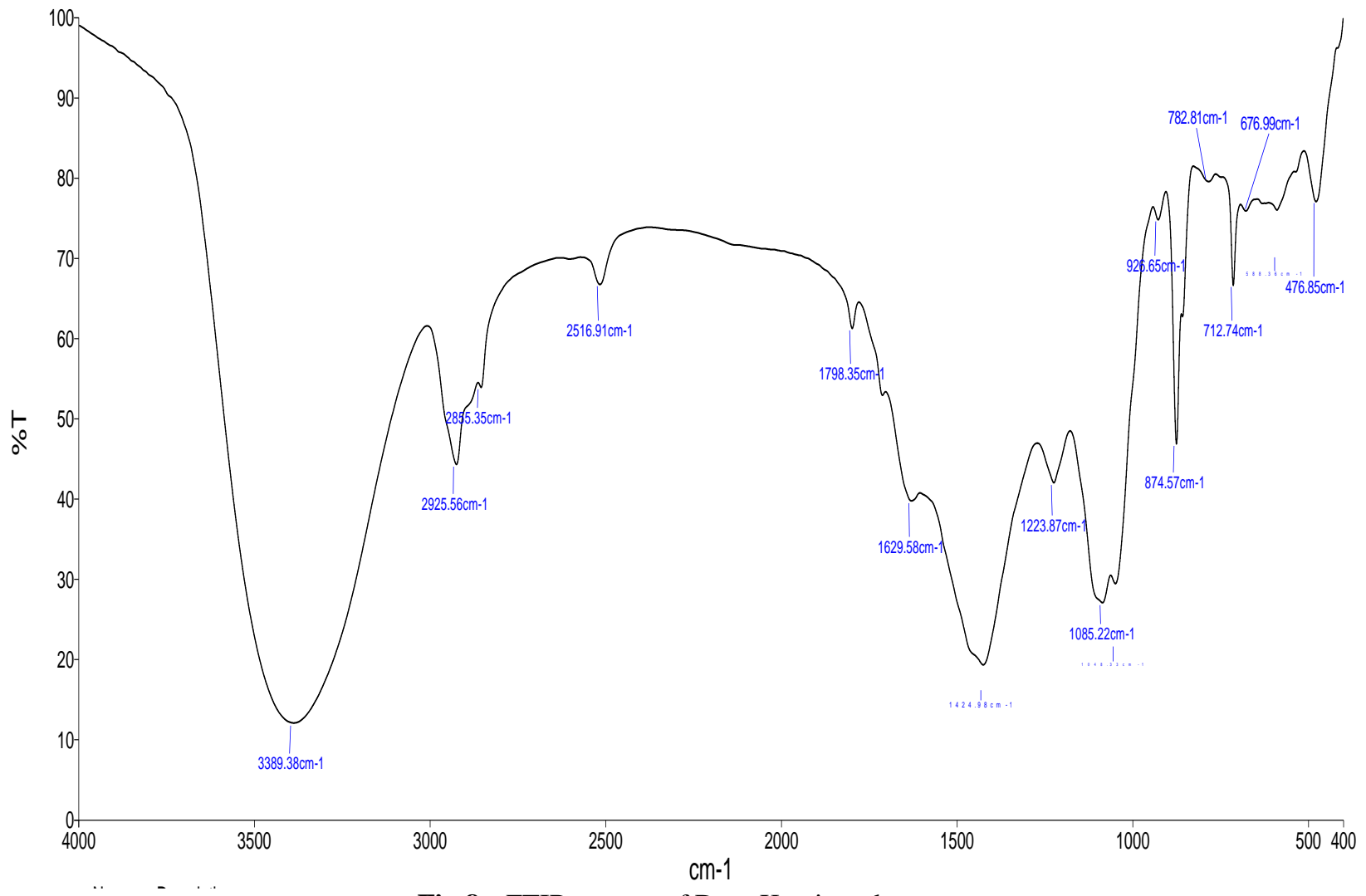

Fig 8:- FTIR spectra of Dant Kanti toothpaste

The FTIR spectrum of the film formed on the metal surface after immersion in artificial saliva containing toothpaste Dant Kanti is shown in Fig 9. A shift is observed in the peak due to O-H stretching frequency from $3389.38 \mathrm{~cm}^{-1}$ to $3411.85 \mathrm{~cm}^{-1}$. Peaks due to C-H stretching frequency have shifted from $2855.37 \mathrm{~cm}^{-1}$ to $2883.46 \mathrm{~cm}^{-1}$ and 2925.56 $\mathrm{cm}^{-1}$ to $2950.00 \mathrm{~cm}^{-1}$. S-H stretching frequency $2516 \mathrm{~cm}^{-1}$ has disappeared as sulphur atom of S-H group having lone pair of electrons has co-ordinated strongly to gold ion and formed a complex. Again a shift is observed in $\mathrm{C}=\mathrm{O}$ stretching frequency from $1798.35 \mathrm{~cm}^{-1}$ to $1715.21 \mathrm{~cm}^{-1}$ and $1629.58 \mathrm{~cm}^{-1}$ to $1585.75 \mathrm{~cm}^{-1}$. Peaks due to P-O stretching frequency have shifted from $1085.22 \mathrm{~cm}^{-1}$ to $1088.80 \mathrm{~cm}^{-1}$ and $1048.33 \mathrm{~cm}^{-1}$ to $1021 \mathrm{~cm}^{-1}$. Peak for C-N stretching has shifted from $1085.22 \mathrm{~cm}^{-1}$ to $1088.80 \mathrm{~cm}^{-1}$ and for $\mathrm{P}=\mathrm{O}$ stretching has shifted from $1223.87 \mathrm{~cm}^{-1}$ to $1223.35 \mathrm{~cm}^{-1}$. A shift was also observed in frequency due to aromatic ring from $1424.98 \mathrm{~cm}^{-1}$ to $1420.78 \mathrm{~cm}^{-1}$. 


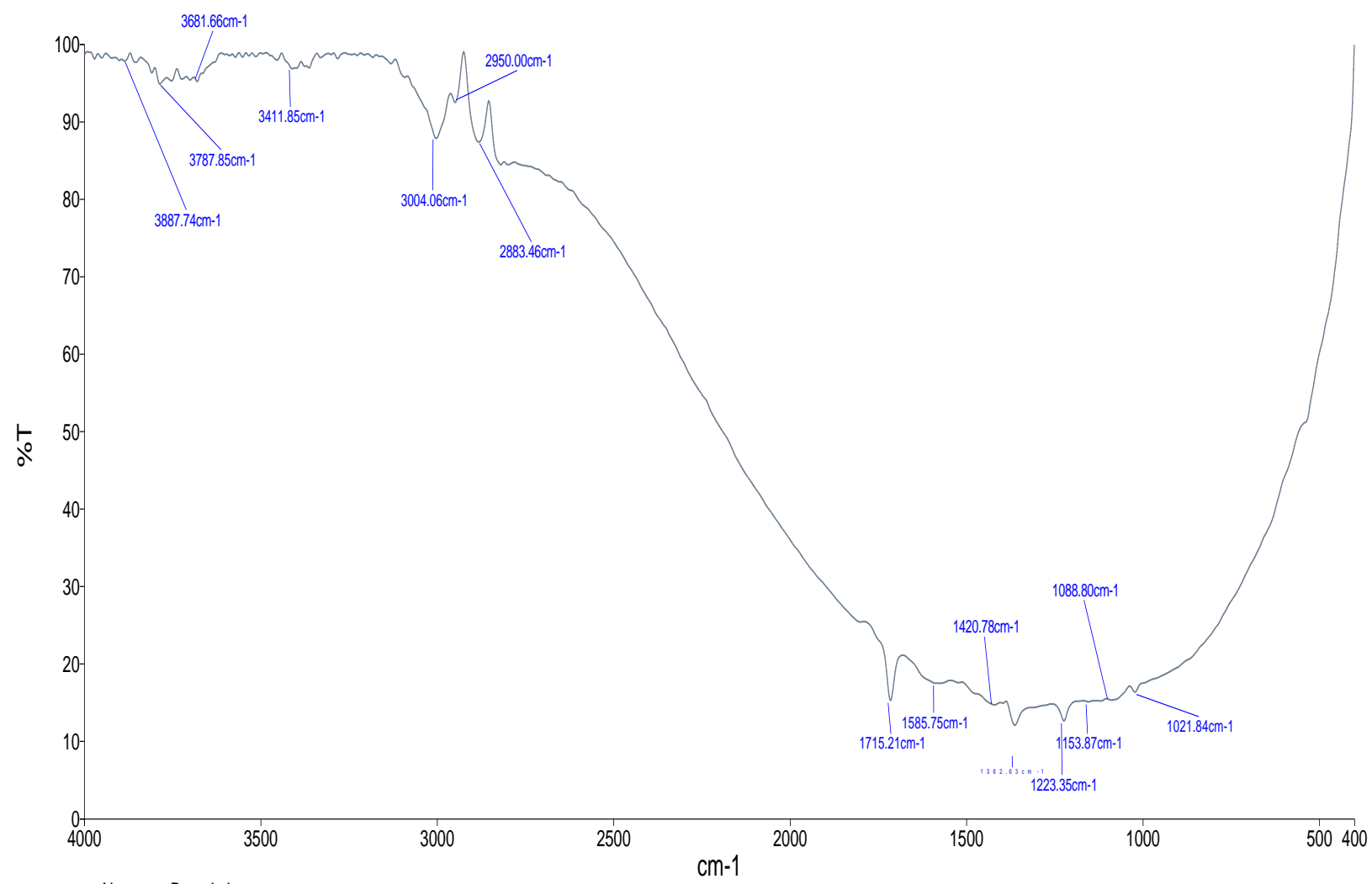

Fig 9:- FTIR spectra of film containing 18ct gold +AS+ Dant Kanti toothpaste (1\%)

This result suggests that the active principles present in ingredients of toothpaste Dant Kanti have coordinated with the metal through oxygen atom of $\mathrm{OH}$ group, $\mathrm{C}=\mathrm{O}$ group and $\mathrm{PO}$ group and sulphur atom of $\mathrm{S}-\mathrm{H}$ group and nitrogen atom of $\mathrm{C}-\mathrm{N}$ group.

\section{Analysis of UV-visible absorption spectra:-}

The UV- visible absorption spectrum is used to confirm the protective film formed on the metal surface. The UVvisible absorption spectrum of artificial saliva is shown in Fig10. Peaks appear at $352 \mathrm{~nm}, 480 \mathrm{~nm}$ and $660 \mathrm{~nm}$. The UV- visible absorption spectrum of toothpaste solution is shown in Fig11. A peak appears at $380 \mathrm{~nm}$. The UVvisible absorption spectrum of the solution of AS toothpaste system wherein 18ct gold has been immersed for one day is shown in Fig12. A peak appears at $388 \mathrm{~nm}$. There is a shift in the position of $\lambda_{\max }$. This is due to the slight dissolution of 18ct gold in presence of AS + toothpaste system. During this process the metal ions such as $\mathrm{Au}^{2+}$ and $\mathrm{Cu}^{2+}$ would have been released. These ions form complexes with the active principles of the ingredients of the toothpaste in solution. So this shift in $\lambda_{\max }$ may be due to the formation of a metal-inhibitor complex.

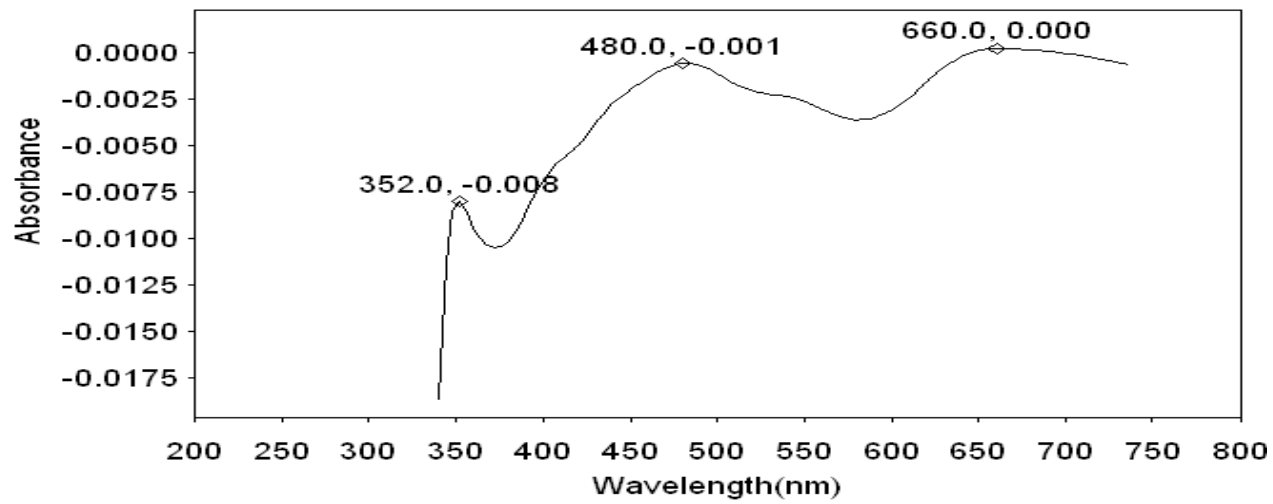

Fig 10:- UV-Visible absorption spectrum of artificial saliva. 


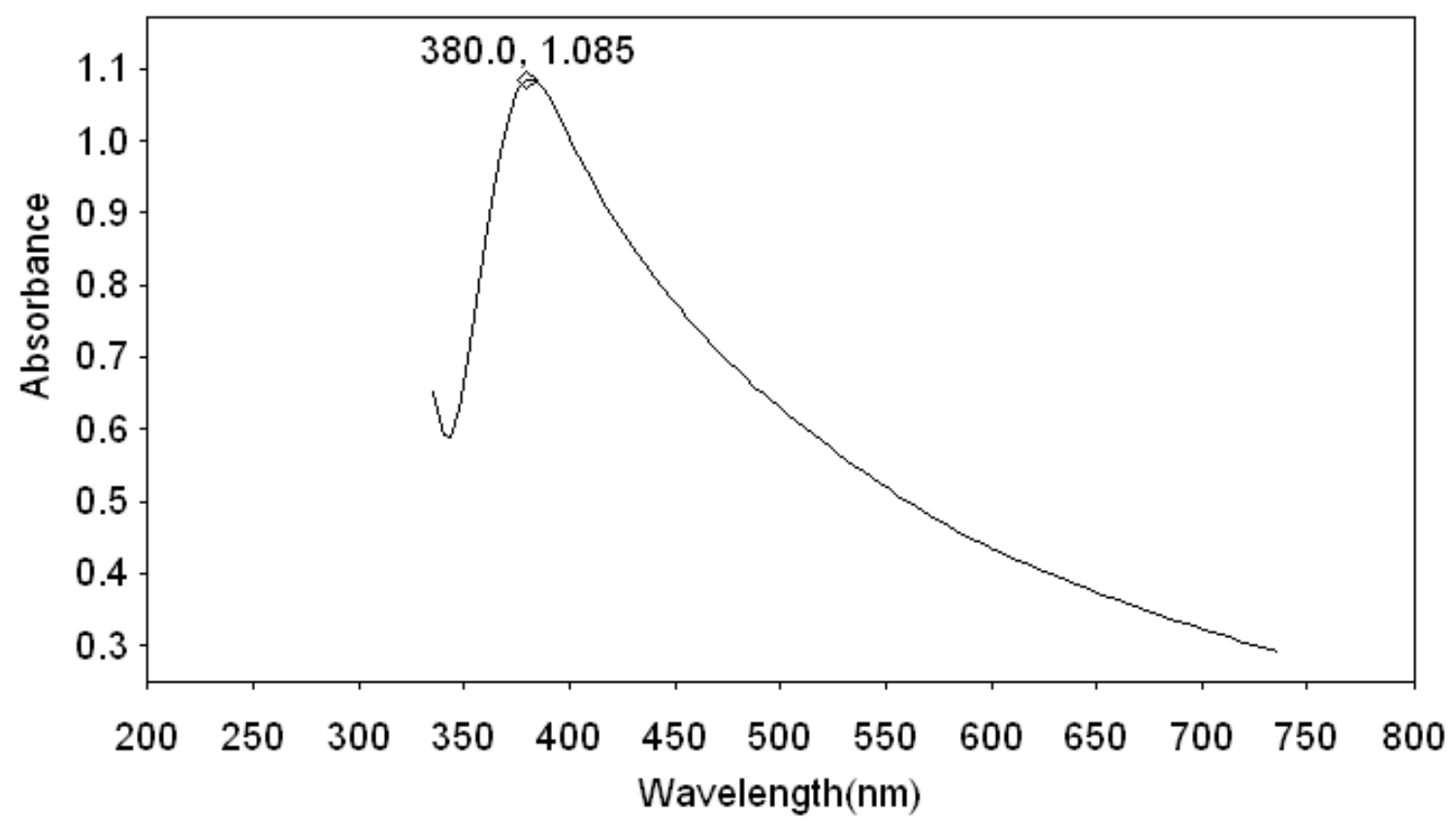

Fig 11:- UV-Visible absorption spectrum of solution containing Dant Kanti toothpaste.

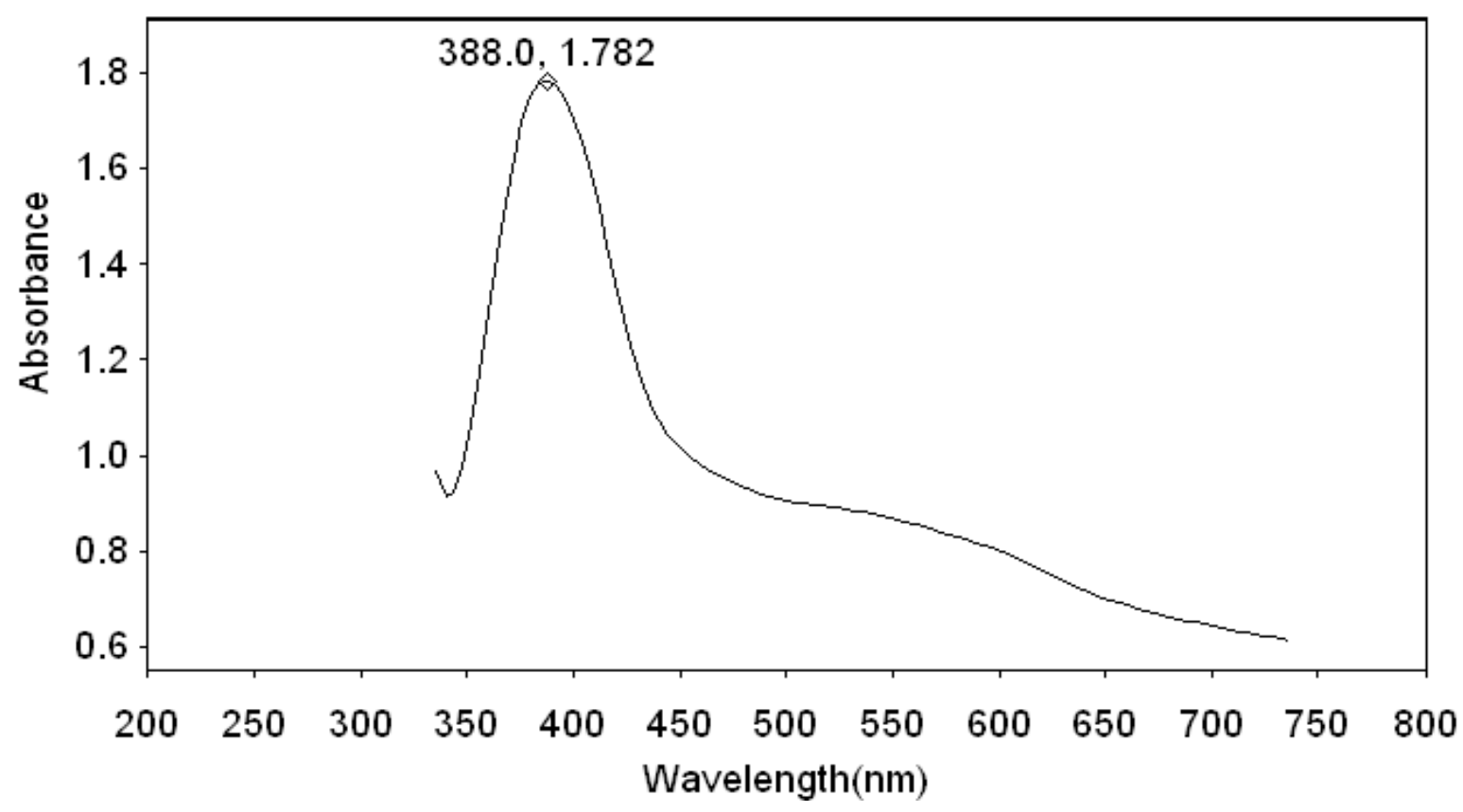

Fig 12:- UV-Visible absorption spectrum of solution containing 18ct gold + AS+ Dant Kanti toothpaste.

\section{Analysis of Fluorescence spectra:-}

Fluorescence spectrum is used to detect the presence of metal - inhibitor complex formed on the surface of 18ct gold alloy. The emission spectrum ( $\lambda_{\mathrm{ex}}=300 \mathrm{~nm}$ ) of artificial saliva is shown in Fig 13. A peak appears at $378.5 \mathrm{~nm}$. The emission spectrum $\left(\lambda_{\mathrm{ex}}=300 \mathrm{~nm}\right.$.) of an aqueous solution of Dant Kanti toothpaste is shown in Fig 14. Emission takes place at $382 \mathrm{~nm}$. 18ct gold was immersed in an aqueous solution containing artificial saliva and the toothpaste Dant Kanti. A solution was obtained. The emission spectrum $\left(\lambda_{\mathrm{ex}}=300 \mathrm{~nm}\right)$ of this solution is shown in fig 15 . The peaks appear at $392 \mathrm{~nm}$ and $454 \mathrm{~nm}$. There is slight shift in $\lambda_{\max }$. This may be due to the release of some $\mathrm{Cu}^{2+}$ 
and $\mathrm{Au}^{2+}$ ions in this system. The appearance of two peaks may be attributed to the formation of a asymmetric complex between metal and the active principles of the ingredient of toothpaste. There is blue light emission. The blue emitting complexes may find application as organic light-emitting device materials.

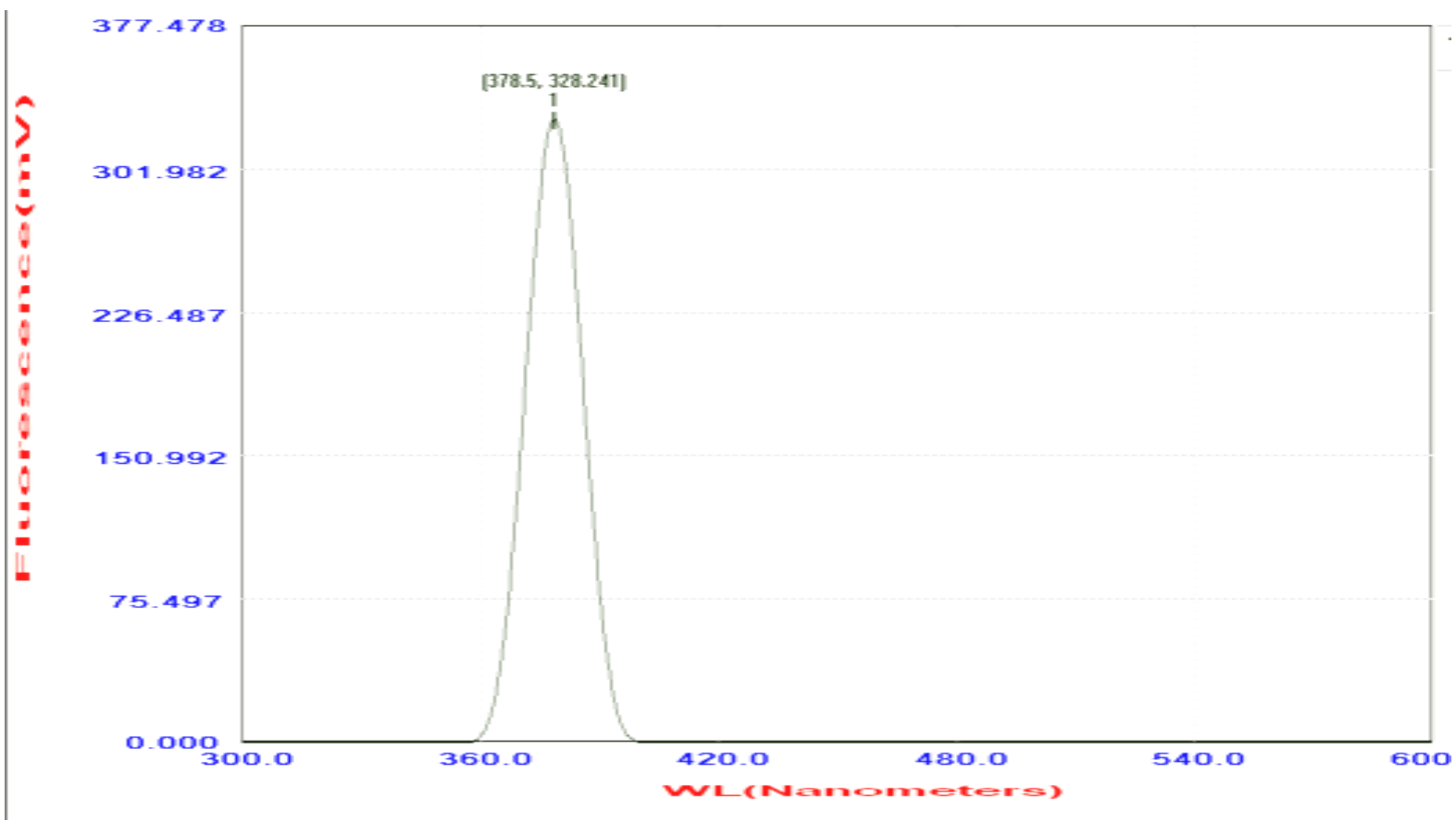

Fig 13:- Fluorescence spectrum of artificial saliva solution.

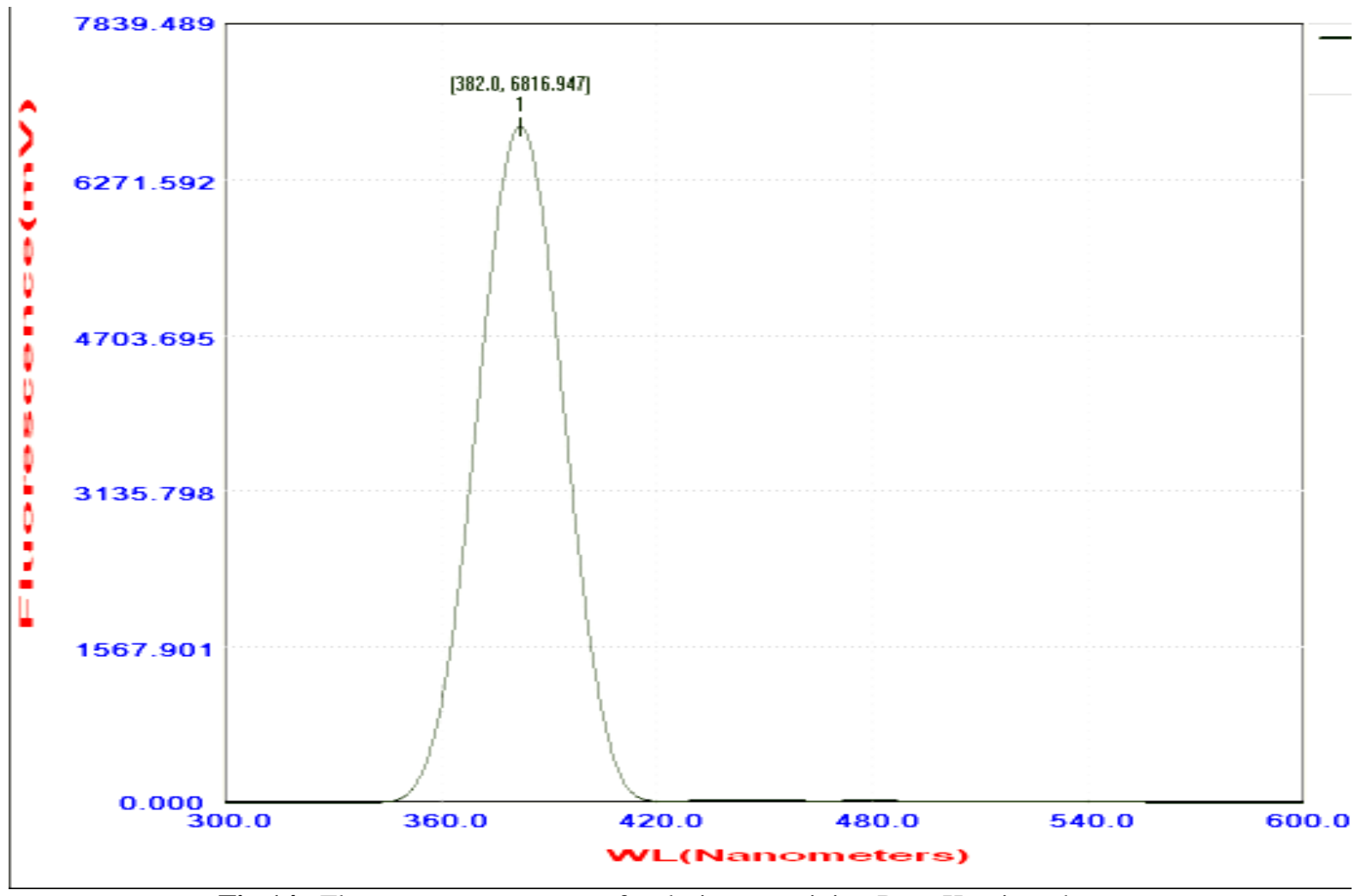

Fig 14 : Fluorescence spectrum of solution containing Dant Kanti toothpaste 


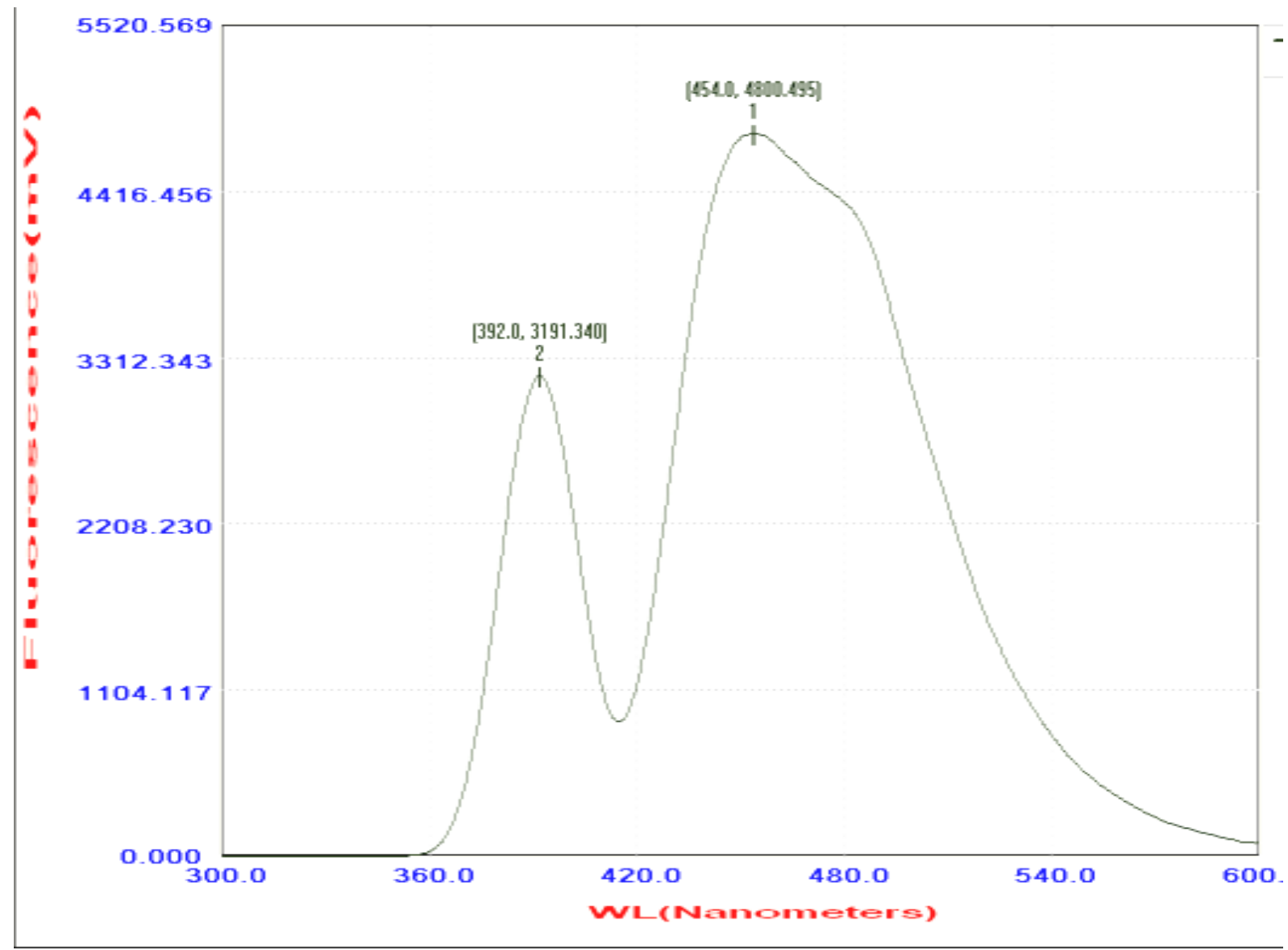

Fig 15 : Fluorescence spectrum of solution containing 18ct gold + AS+ Dant Kanti toothpaste

\section{Conclusions:-}

The corrosion resistance of $18 \mathrm{ct}$ gold in artificial saliva in the absence and the presence of toothpaste Dant Kanti has been evaluated by electrochemical studies such as polarization and AC impedance spectra and surface characterization studies such as SEM, EDAX, FTIR, UV-Visible absorption and fluorescence spectra. It is observed that the corrosion resistance of $18 \mathrm{ct}$ gold is more in the presence of toothpaste than in the presence of artificial saliva only. In the presence of artificial saliva and toothpaste the corrosion resistance still increases. This is due to the fact that the active principles of the ingredients of the toothpaste would have coordinated with the metal ion through their polar groups such as oxygen, nitrogen and sulphur forming a protective layer on the surface of the metal. The corrosion resistance increases in the order: AS+toothpaste >toothpaste>AS. The implication of this study is that people who have been implanted with orthodontic wires made of $18 \mathrm{ct}$ gold need not hesitate to clean their teeth with Dant Kanti toothpaste.

\section{Acknowledgement:-}

The authors are thankful to their respective departments for the help and encouragement. 


\section{References:-}

1. Amini, F., Rakhshan, V., Mesgarzadeh, N. (2012): Effects of long-term fixed orthodontic treatment on salivary nickel and chromium levels: a 1-year prospective cohort study. Biol Trace Elem Res., 150: 15-20.

2. Christoper, M. A., Brett. and IoanaMuresan. (2002): The influence of artificial body fluids on metallic corrosion. Eng Mater., 230-232: 459-462.

3. Duff, G. S. and Farina, S. B.(2009): Corrosion behaviour of a dental alloy in some beverages and drinks. Materials Chemistry and Physics., 115(1): 235-238.

4. Fernandez-Minano, E., Ortiz, C., Vincente, A. et al (2011): Metallic ion content and damage to the DNA in oral mucosa cells of children with fixed orthodontic appliances. Biometals., 24: 935-41.

5. Harzer, W., Schröter, A., Gedrange, T. and Muschter, F. (2001): Sensitivity of titanium brackets to the corrosive influence of fluoride-containing toothpaste and tea. Angle Orthod., 71: 318-23.

6. House, K., Sernetz, F., Dymock, D., et al (2008): Corrosion of orthodontic appliances-Should we care?. Amer. J. Orthodontics Dentofacial Orthopedics., 133(4): 584-592 .

7. Klimek, L. (2005): Structure and corrosion resistance of the layers of titanium nitride and carbo nitride alloy for dental Wironit. Engineering of Biomaterials., 43-44 : 40-43

8. Krishnaveni, A., Rajendran, S. and Pandiarajan, M. (2013): Corrosion resistance of 18 carat gold in saliva containing Almox 250DT. Eur. Chem. Bull., 2(8): 558-561.

9. Meyer, J. M. (1977): Corrosion resistance of nickel-chromium dental casting alloys. Corro. Sci., 17: 971-982.

10. Pop S.-I., Dudescu, M., Bratu D. C., Pop R.-V., Petrisor, M., Pacurar M. (2013): Influence of the chemical composition on the mechanical properties of orthodontic archwires. Rev. Chim., 64(7): 771-775.

11. Rajendran, S., Paulraj, J., Rengan, P., Jeyasundari, J., Manivanan, M. (2009): Corrosion behavior of metals in artificial saliva in presence of spirulina powder. J Dentistry Oral Hug., 1(1):001-008

12. Sfondrini, M. F., Cacciafesta, V., Maffia, E. et al (2009): Chromium release from new stainless steel, recycled and nickel-free orthodontic brackets. Angle Orthod., 79: 361-67 